Article

\title{
Evaluating the Tradeoffs between Groundwater Pumping for Snow-Melting and Nearshore Fishery Productivity in Obama City, Japan
}

\author{
Kimberly M. Burnett ${ }^{1, *(\mathbb{D}}$, Christopher A. Wada ${ }^{1}\left({ }^{1}\right.$, Makoto Taniguchi $^{2}$, Ryo Sugimoto $^{3} \mathbb{D}$ and \\ Daisuke Tahara ${ }^{3}$ \\ 1 University of Hawaii Economic Research Organization, Honolulu, HI 96822, USA; cawada@hawaii.edu \\ 2 Research Institute for Humanity and Nature, Kyoto 603-8047, Japan; makoto@chikyu.ac.jp \\ 3 Research Center for Marine Bioresources, Fukui Prefectural University, Fukui 910-1195, Japan; \\ sugiryo@fpu.ac.jp (R.S.); tahara@fpu.ac.jp (D.T.) \\ * Correspondence: kburnett@hawaii.edu; Tel.: +1-808-956-8068
}

Received: 23 September 2018; Accepted: 28 October 2018; Published: 1 November 2018

\begin{abstract}
Groundwater is used in Obama City, Japan, to melt snow ( $13 \%$ of total groundwater use) during the winter, the remainder being used for mostly domestic purposes, such as drinking water. Due to concern about the impacts of this snow-melting practice on nearshore marine resources, we estimate the benefits and costs of increasing the volume of the groundwater used for snow-melting by $50 \%$. Assuming that the outcome is the same for all possible snow-melting techniques-snow effectively removed from roads - the primary benefit of the use of groundwater for snow-melting is the avoided cost of, or cost savings relative to, alternative technologies. The costs include losses to nearshore fishery productivity, due to a decline in submarine groundwater discharge (SGD), and increased energy expenditures on groundwater pumping, used to supply the snow-melting system. Our results suggest that the net benefit of increasing the use of groundwater to melt snow by 1.5 times its current rate in Obama is positive, and that the annual net benefit ranges from 10.9 million JPY/year to 547.7 million JPY/year. Because the cost of operating the groundwater system is relatively low, the net benefit of continuing to use groundwater for snow-melting becomes negative only if the impact on fishery productivity is substantial.
\end{abstract}

Keywords: groundwater management; submarine groundwater discharge; water-energy-food nexus; nearshore fishery; Obama City, Japan

\section{Introduction}

Annual use of freshwater in Japan is approximately 83.5 billion $\mathrm{m}^{3}, 12 \%$ (10.8 billion $\left.\mathrm{m}^{3}\right)$ of which is supplied by groundwater [1]. However, that share varies widely across regions. In Fukui Prefecture, located on the west coast of Honshu, for example, $70 \%$ of municipal use is supplied by groundwater [2]. The need to efficiently manage groundwater resources in such areas is amplified by projected impacts of climate change on water resources. With the exception of a few river basins, water supply is expected to decrease in Japan [3], largely due to an expected increase in rainfall variability and the risk of drought [4]. Studies have shown that when sources of surface water are stochastic, the value of groundwater as a buffer to mitigate surface supply fluctuations can be substantial $[5,6]$.

In addition to concerns about future scarcity of water resources for drinking and other human uses, increasing attention has been paid in recent years to ecosystems that depend on groundwater systems [7-11]. MacKay [12] notes, in particular, the challenge of "protecting groundwater-dependent ecosystems, while still allowing the use of groundwater to support social and economic development, 
poverty alleviation, and improved food and water security". This issue is particularly relevant to islands such as Japan, because ecosystem linkages can exist in both terrestrial areas and along the coasts. Though frameworks to integrate groundwater management and ecosystem service provision have been developed over the past decade $[13,14]$, most research in this area has focused on determining the thresholds required to maintain a minimum level of services [15]. In this study, we are able to more directly evaluate the tradeoff between aboveground groundwater uses and a linked nearshore marine ecosystem in monetary terms, because the latter supports a commercial fishery whose value is reflected by market transactions.

Because of its constant and relatively warm temperature, groundwater is currently being used at our study site (Obama City, Japan) to melt snow ( 13\% of total groundwater use in 2011) during the winter, the remainder being used for mostly domestic purposes such as drinking water. However, there has been some concern in recent years about the impacts of this snow-melting practice on nearshore marine resources. Our research focus on Obama's coastal marine ecosystem was guided by stakeholder concerns in the region, but, more generally, there are a number of other types of groundwater-dependent ecosystems that could be affected by changes in groundwater withdrawals. These include: Aquatic ecosystems that depend on the discharge from the groundwater flow that rises to the surface as springs; wetland ecosystems, related to the discharge of shallow groundwater flow systems, aquatic ecosystems that depend on the groundwater discharge providing dry-weather flow in the upper reaches of river systems; terrestrial ecosystems, with deep-rooted phreatophytic vegetation, that extract groundwater directly from the water table; and aquifer and cave ecosystems [11,14]. Guided by the Obama Groundwater Commission's expectations, we estimate the benefits and costs of increasing the volume of groundwater used for snow-melting by $50 \%$. Assuming that the outcome is the same for all possible snow-melting techniques-snow effectively removed from roads—-the primary benefit of the use of groundwater for snow-melting is the avoided cost of, or cost savings relative to, alternative technologies. The costs include losses to nearshore fishery productivity, due to a decline in submarine groundwater discharge (SGD), and increased energy expenditures on groundwater pumping, used to supply the snow-melting system.

\section{Methods}

\subsection{History of Groundwater Use in Obama City}

Obama is a city located south of Wakasa Bay in the Fukui Prefecture of Japan (Figure 1). The mixture of cold and warm currents in the bay, combined with nutrients supplied by submarine groundwater discharge (SGD) along the coast, provides a fertile nearshore environment for the city's fishing industry. In fact, the fishery resource was historically so productive that it became recognized as "miketsukuni" - a region responsible for supplying food to the imperial court. In addition to supporting the fishing industry, groundwater resources in the Obama area provide the city's $\sim 31,000$ residents with freshwater for domestic, commercial, municipal, industrial, and limited agricultural uses. Following a peak in 2011, annual supplied groundwater has been on the decline, likely owing to Obama's shrinking population [16]. However, the demand for groundwater to melt snow on city roads is expected to increase in the near future, resulting in an interesting tradeoff between a direct (snow-melting) and indirect (SGD maintenance to support fishery productivity) use of the water resource. Understanding this tradeoff becomes even more important if groundwater scarcity increases in the future due to other factors, such as climate-induced recharge decline, land use change (e.g., increased urban development), and/or population growth. A more general framework would allow for variation in multiple aboveground water uses and the consequent impacts on multiple-linked resources, such as fisheries. 


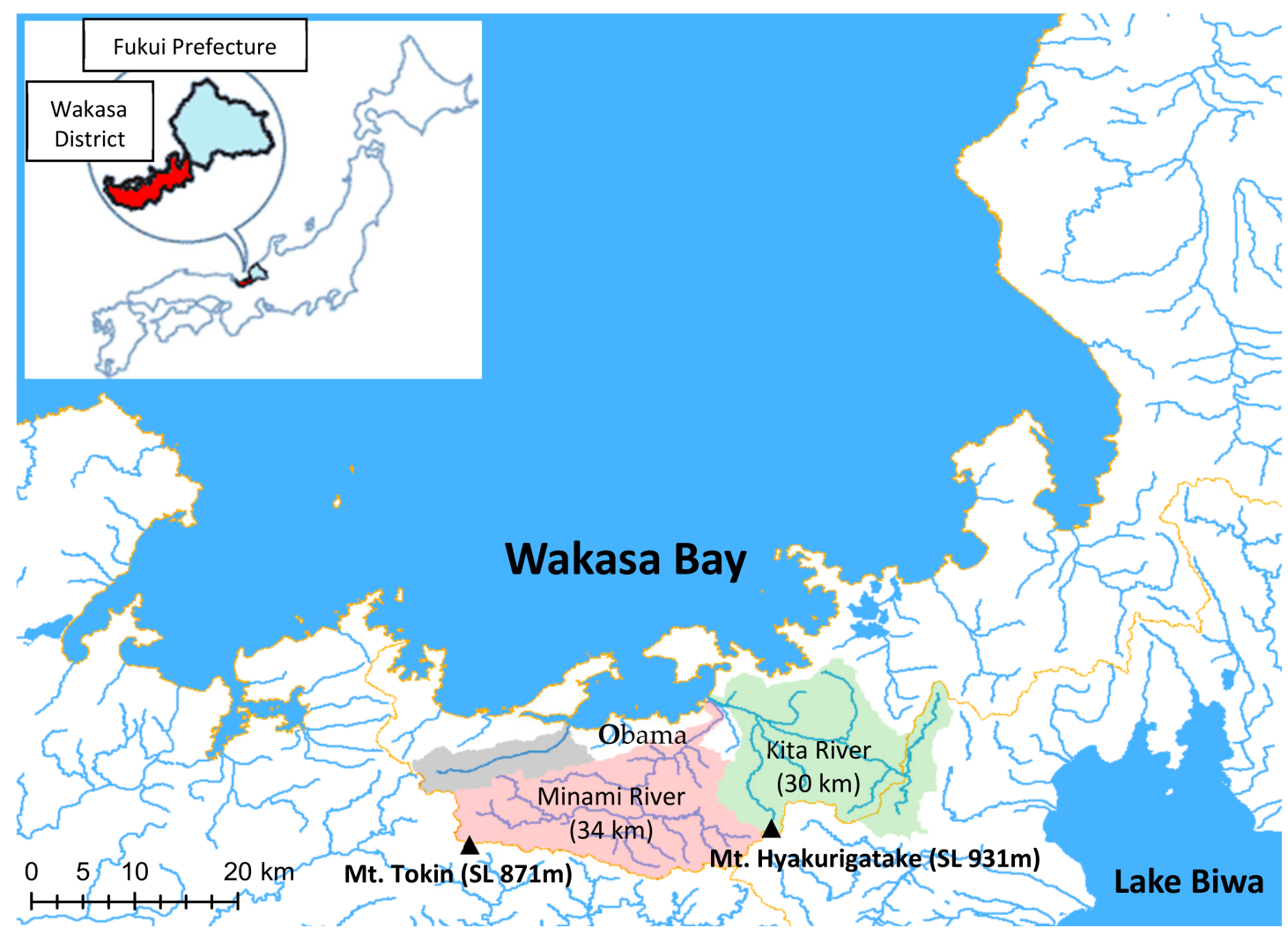

Figure 1. Map of the Wakasa District in Fukui Prefecture, including Obama City and the surrounding area.

\subsection{Avoided Cost of Groundwater Alternatives for Melting Snow}

Increasing the volume of groundwater used to melt snow in Obama during winter months potentially reduces SGD, and subsequently the productivity in the nearshore fishery. However, if melting snow using groundwater is less costly than alternative technologies, the costs avoided by not having to use one of those alternatives can be viewed as a benefit that may offset losses imposed on the fishery. In order to estimate the cost savings of groundwater relative to other snow-melting options, cost data was collected for six alternatives: Manual, heat pump, oil, gas, filament, and air pump. The manual option includes shoveling, plowing, and similar mechanical removal techniques; the heat pump approach melts snow by circulating hot water through infrastructure embedded in the road; and filament systems melt snow using electricity sent through infrastructure laid over the pavement. For each alternative, the unit cost was multiplied by the area of the road treated and the expected number of snow days per winter to calculate the total avoided cost per year.

\subsection{Cost of Groundwater for Melting Snow}

Although the application of groundwater for melting snow in Obama is largely automated, electricity is required for transmitting the water from pump stations to the application sites, and the system requires regular maintenance and repairs. In addition, energy is required to pump the groundwater to the surface, before it is fed into the distribution network. The total annual pumping cost was estimated by multiplying the unit pumping cost by the volume of water required to treat the total area of road at the study site for the expected number of snow days per winter. Total annual transmission and maintenance costs were estimated by multiplying the daily cost of system operation in 2017 by the expected number of snow days per winter.

If not for the potentially negative impact of increased groundwater use on the nearshore fishery, and assuming groundwater alternatives do not themselves generate any negative externalities to the environment, the optimal snow-melting option would be determined by a simple comparison of 
operations costs. In other words, in the absence of externalities, the snow-melting option with the lowest operations cost is most cost-effective. For our study site, however, we estimated the monetary impact on the fishery, of a simulated increase in pumping for snow-melting, that should be included as an additional cost of groundwater use when comparing options.

An increase in groundwater withdrawals could also have a negative effect on the quality of both the water being pumped for use and the water discharging into the bay [17]. Although our study does not consider water quality, such impacts, if quantifiable and monetizable, could be included as additional costs of using groundwater for melting snow.

\subsection{Nearshore Fishery Production Losses}

Estimating the impact of groundwater pumping for snow-melting on nearshore fisheries required several steps: (i) Calibrating and validating a water balance and groundwater flow model that can simulate the effect of pumping decisions on SGD; (ii) linking changes in SGD to fish production; and (iii) using fishery management data to calculate the change in net revenue associated with the reduction in fish production.

The effect of groundwater pumping on SGD was simulated using two numerical models [18]. First, water balance in the Kita River basin $\left(213 \mathrm{~km}^{2}\right)$ and Minami River basin $\left(224 \mathrm{~km}^{2}\right)$ (Figure 2) was simulated with the SHER (similar hydrologic element response) model, using hydrometeorological data from those areas. The MODFLOW (modular finite-difference groundwater flow) model was then used to simulate three-dimensional groundwater flow in the alluvial plain $\left(55 \mathrm{~km}^{2}\right)$, which included Obama City (Figure 2). Observed river discharge rates of the Kita and Minami rivers were validated by the SHER model to evaluate water budget components, such as groundwater recharge rates. Groundwater levels were validated by the MODFLOW model to evaluate components such as SGD.

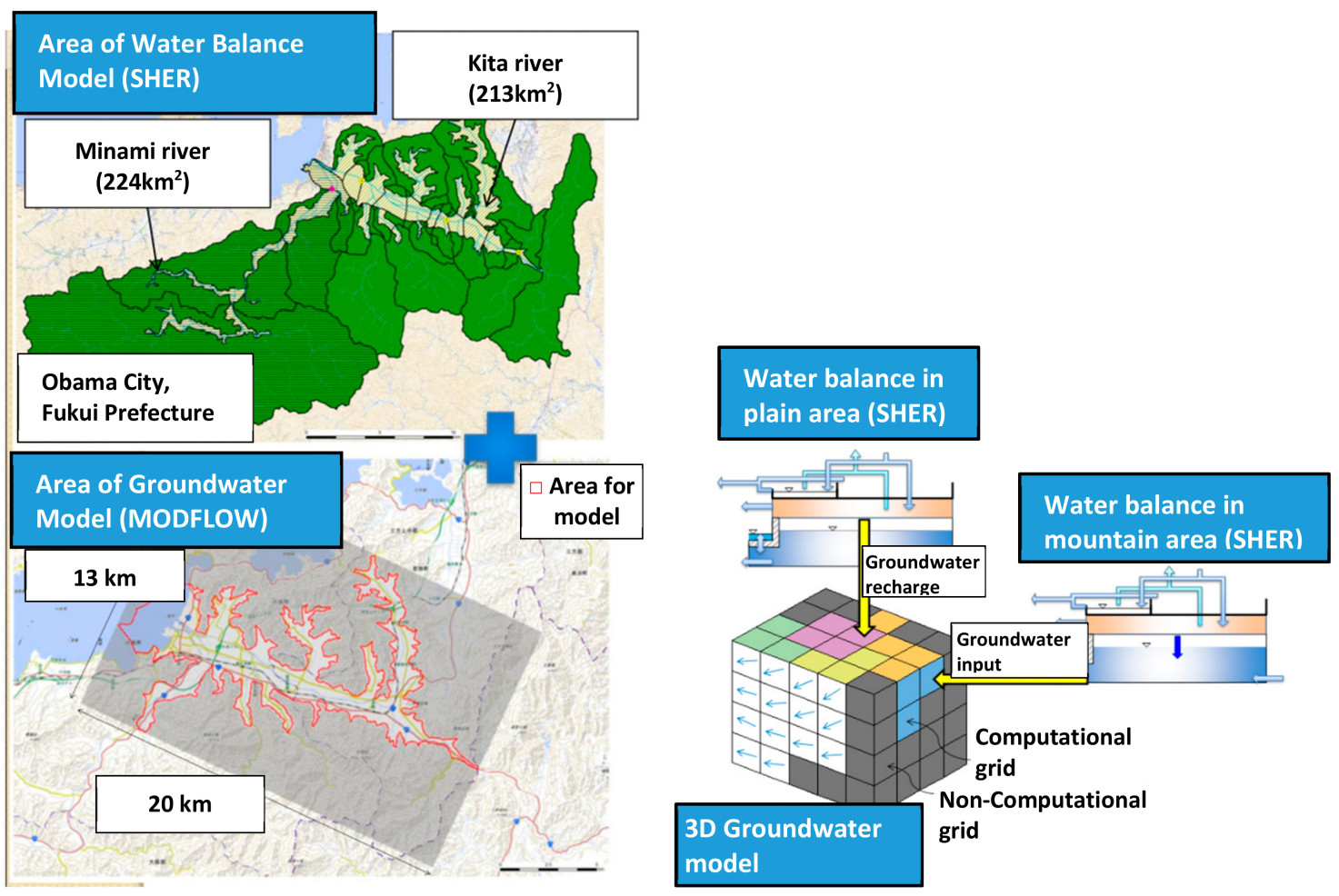

Figure 2. Model areas and interactions between the water balance (similar hydrologic element response (SHER)) and 3D groundwater (modular finite-difference groundwater flow (MODFLOW)) models. 
A decrease in SGD reduces the flow of nitrogen, phosphorus, silica and other nutrients into the ocean, which affects primary production and, ultimately, fishery production (Figure 3). To estimate the impact of a simulated change in SGD on fishery productivity, we first estimated baseline fishery production along the Obama coast using the following relationship [19]: $\mathrm{P}=\mathrm{BEn}$, where $\mathrm{P}$ is secondary production in a particular trophic level, B is annual primary production, E is ecological efficiency for the food chain, and $\mathrm{n}$ is the number of trophic transfers (which equals the number of trophic levels minus 1). Fishery production was then estimated assuming a 50\% increase in the groundwater pumped for snow-melting, a likely scenario given shifting technologies and population distributions in Obama (Obama Groundwater Commission, pers. comm.). The difference in fish production for the two groundwater pumping scenarios (baseline and $+50 \%$ ) was used as a measure of fishery impact. Although not captured in our model, there is a possibility that the simulated change in SGD could have a disproportionate effect on certain fish and aquatic plant species, which could cause a shift in biodiversity in the bay [20-22]. In that case, our general approach would remain valid but would require estimating fishery production losses on a species by species basis to account for the non-uniform effect.

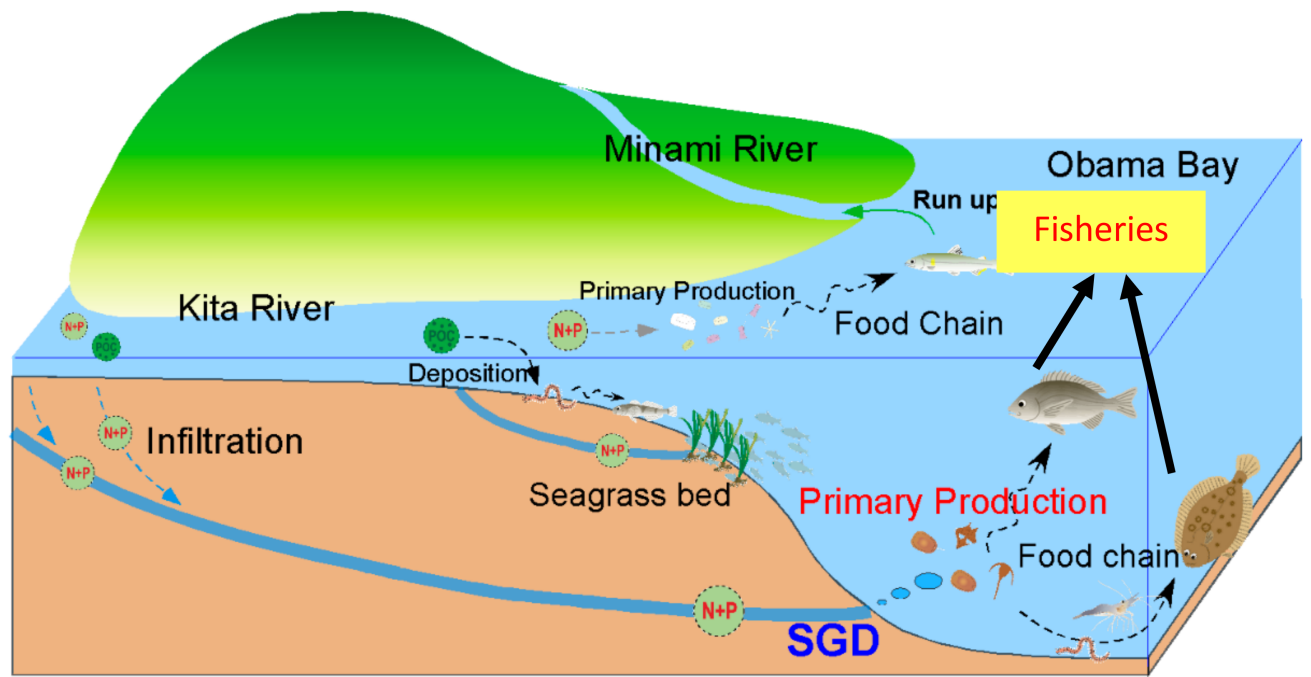

Figure 3. Link between submarine groundwater discharge (SGD) and fisheries productivity in Obama Bay.

To monetize the fishery impact, we multiplied the change in fishery production (due to the reduction in SGD) by average net revenue for fishing boats in Obama that reported harvesting 0-10 tons annually. Gross revenue was estimated using Obama fishery catch and price data from December 2017 [23]. The proportion of each species to total catch was calculated and multiplied by the simulated change in total fishery production to extrapolate the change in volume by species. Each measure of fish volume was then multiplied by the appropriate market price to estimate the change in revenue by species. The sum of those changes represented the total impact in terms of gross revenue. Fishing capital and variable expenditure data (labor, equipment, fuel, bait, maintenance, sales commission, taxes, depreciation, etc.) were obtained for the most recent year available [24]. Monetized annual fishery impact, in terms of net revenue, was then calculated as the difference between gross fishing revenue and costs over a three-month winter season, during which groundwater is typically used to melt snow. In reality, the SGD effect may continue beyond the winter season, so our estimated impact is conservative. 


\section{Results}

\subsection{Avoided Cost of Groundwater Alternatives for Melting Snow}

At the Obama study site, winters in recent years have averaged 15 days of snowfall, with up to 29 days of accumulated snow. The total length of road requiring snow-melting is approximately $6 \mathrm{~km}$. Given an average road width of $5 \mathrm{~m}$, the total treatment area spans $30,000 \mathrm{~m}^{2}$.

Manual snow removal would incur labor costs ranging from 10,000 JPY/person/day (retired wage) to 16,200 JPY/person/day (market wage), and we assumed a fixed removal efficiency of $25 \mathrm{~m}^{2}$ / person/day. Other snow-melting alternatives would incur primarily non-labor costs, such as energy. Unit costs were estimated at $1.8,3.6,4.5,4.8$, and $8.8 \mathrm{JPY} / \mathrm{m}^{2} / \mathrm{h}$ for heat pump, oil, air pump, gas, and filament snow-melting techniques, respectively. To represent a range of avoided costs, we calculated expected annual snow-melting expenses for each alternative technology, for both 15 and 29 snow days (Table 1). Estimated costs ranged from a low of 19.4 million JPY per winter (heat pump operated for 15 snow days) to a high of 563.8 million JPY per winter (manual removal at market wage for 29 snow days).

Table 1. Estimated annual costs of differing snow-melting technologies (million JPY/year).

\begin{tabular}{ccc}
\hline Technology & 15 Snow Days & 29 Snow Days \\
\hline Manual (retired) & 180.0 & 348.0 \\
Manual (market) & 291.6 & 563.8 \\
Heat pump & 19.4 & 37.6 \\
Oil & 38.9 & 75.2 \\
Air pump & 48.2 & 101.2 \\
Gas & 52.3 & 183.7 \\
Filament & 95.0 & 93.3 \\
Groundwater & 8.2 & 15.8 \\
\hline
\end{tabular}

\subsection{Cost of Groundwater for Melting Snow}

Currently, $0.379 \mathrm{~m}^{3} / \mathrm{m}^{2} /$ day of groundwater is used to melt snow in Obama during winter months [18]. Therefore, given a treatment area of $30,000 \mathrm{~m}^{2}$, the total required groundwater was estimated at 170,550 and 329,730 $\mathrm{m}^{3}$ for 15 and 29 snow days, respectively. Assuming an average unit pumping cost of $8.5 \mathrm{JPY} / \mathrm{m}^{3}$, based on data from the Yuno-oka $\left(7.95 \mathrm{JPY} / \mathrm{m}^{3}\right)$ and Onyu $\left(9.0 \mathrm{JPY} / \mathrm{m}^{3}\right)$ water sources in Obama [25], the annual pumping cost of groundwater for snow-melting was estimated at 1.4 and 2.8 million JPY for 15 and 29 snow days, respectively. In addition to pumping costs, the average daily cost of operating the groundwater snow-melting system-including transmission, electricity, maintenance, and repair costs-was estimated at $\sim 450,000 \mathrm{JPY}$ in 2017 . The total cost of the groundwater used for melting snow amounted to 8.2 and 15.8 million JPY for 15 and 29 snow days, respectively.

\subsection{Nearshore Fishery Production Losses}

Nippon Koei Co., Ltd. [18] applied the developed groundwater model to simulate future hydrological responses in Obama to different scenarios of climate and water use. Through discussions with local government officials, it became clear that there was interest in assessing potential impacts of an increase in the demand for the groundwater used to melt snow. We focused on the scenario in which groundwater pumped for snow-melting is increased by 1.5 times its current volume. Results from the model show that a 50\% increase in groundwater pumping decreases total SGD (1 million $\left.\mathrm{m}^{3}\right)$ by $5 \%$ or $50,000 \mathrm{~m}^{3}$ per year.

Dissolved inorganic phosphorus (DIP) flux by SGD into Obama Bay was recently estimated at $14 \times 10^{3} \mathrm{~kg}-\mathrm{P}$ year $^{-1}$ [26]. Applying the Redfield ratio of C:N:P = 106:16:1, implied potential primary production, $B$, of 570 ton year ${ }^{-1}$. We assumed an ecological efficiency (E) of 0.15 , and number of 
trophic transfers (n) equal to 3 for fish [27]. The secondary production rate $(P)$ was then calculated as $\mathrm{P}=570$ (ton- $\mathrm{yr}^{-1}$ ) $\times 0.15^{3}=1.92$ ton year $^{-1}$. Further assuming that carbon comprises $20 \%$ of each fish body on average, we estimated that 9.6 ton year ${ }^{-1}$ of fish are supported by SGD in Obama Bay. Therefore, 0.48 tons of fish would be lost if SGD were to decrease by $5 \%$, due to a $50 \%$ increase in groundwater pumping for melting snow.

In December 2017, fish catch in Obama ranged from $31 \mathrm{~kg}$ of sandfish ( $<1 \%$ of total catch) to $10,358 \mathrm{~kg}$ of yellowback seabream (14\% of total catch). Prices ranged from $31 \mathrm{JPY} / \mathrm{kg}$ for anchovies up to $4834 \mathrm{JPY} / \mathrm{kg}$ for snow crab (Table 2). Gross revenue potentially lost, due to a 5\% reduction in SGD and the subsequent 0.48 ton loss in fish production, was estimated at 457,393 JPY per winter.

Table 2. Fish volume, prices, and proportion of total catch in Obama (December 2017).

\begin{tabular}{|c|c|c|c|c|}
\hline Fish Species (English Name) & $\begin{array}{c}\text { Fish Species } \\
\text { (Japanese Name) }\end{array}$ & $\begin{array}{l}\text { Catch } \\
(\mathrm{kg})\end{array}$ & Unit Price (JPY/kg) & Proportion of Total Catch \\
\hline Yellowtail & Buri & 1759 & 1238 & 0.02 \\
\hline Young yellowtail & Hamachi & 1406 & 341 & 0.02 \\
\hline Spanish mackerel & Sawara & 3876 & 959 & 0.05 \\
\hline Young Spanish mackerel & Sagoshi & 10,104 & 529 & 0.13 \\
\hline Horse mackerel & Maaji & 3258 & 441 & 0.04 \\
\hline Anchovy & Katakuchiiwashi & 2562 & 31 & 0.03 \\
\hline Flounder & Hirame & 1164 & 1699 & 0.02 \\
\hline Red flounder & Akagarei & 4598 & 720 & 0.06 \\
\hline Willow flounder & Yanagimushigarei & 3666 & 1518 & 0.05 \\
\hline Souhachi flounder & Souhachi & 3934 & 398 & 0.05 \\
\hline Red seabream & Madai & 3645 & 665 & 0.05 \\
\hline Yellowback seabream & Kidai & 10,358 & 549 & 0.14 \\
\hline Red tilefish & Akaamadai & 2769 & 2767 & 0.04 \\
\hline John Dory & Matoudai & 1104 & 897 & 0.01 \\
\hline Monkfish & Ankou & 1264 & 659 & 0.02 \\
\hline Barracuda & Kamasu & 2702 & 446 & 0.04 \\
\hline Filefish & Kawahagi & 2300 & 455 & 0.03 \\
\hline Conger eel & Anago & 1737 & 988 & 0.02 \\
\hline Sandfish & Hatahata & 31 & 677 & 0.00 \\
\hline Octopus & Tako & 1348 & 1329 & 0.02 \\
\hline Snow crab & Zuwaigani & 1039 & 4834 & 0.01 \\
\hline Snow crab (female) & Seikogani & 1434 & 3732 & 0.02 \\
\hline Pacific oyster & Magaki & 1848 & 1017 & 0.02 \\
\hline Sea cucumber & Namako & 498 & 1727 & 0.01 \\
\hline Other & & 8210 & 1323 & 0.11 \\
\hline
\end{tabular}

Annual variable fishery expenditures for ships catching up to 10 tons varied from 2.5 million JPY / year (<3 tons) up to 11.5 million JPY / year (5-10 tons). Capital costs similarly varied according to ship tonnage, ranging from 4.1 million JPY/year ( $<3$ tons) to 12.0 million JPY/year (5-10 tons). Total cost per ton did not vary greatly across ship size; however, ranged from 2.2-2.4 million JPY/ton (Table 3). After adjusting annual values to three-month values, to match the duration of groundwater use for snow-melting, average net revenue loss, from a 5\% decrease in SGD and the subsequent 0.48 ton decline in fish production, totaled 341,070 JPY/winter, if only the variable costs were considered, or 189,003 JPY/winter, if capital costs were also included.

Table 3. Fishing expenditures in Obama by ship tonnage in 2015 (1000 JPY/yr).

\begin{tabular}{cccccc}
\hline Ship Size & Variable & Capital & Total & Variable Per Ton & Total Per Ton \\
\hline$<3$ tons & 2465 & 4127 & 6592 & 822 & 2197 \\
$3-5$ tons & 4661 & 6149 & 10,810 & 932 & 2162 \\
$5-10$ tons & 11,542 & 11,962 & 23,504 & 1154 & 2350 \\
\hline
\end{tabular}




\section{Discussion}

Our results suggest that the net benefit of increasing the use of groundwater to melt snow by 1.5 times its current rate in Obama is positive (Table 4). The annual net benefit ranges from 10.9 million JPY/year (heat pump alternative, 15 snow days, low fishery cost) to 547.7 million JPY/year (manual market labor, 29 snow days, high fishery cost). This result is largely driven by cost differences for snow-melting technologies. Because the cost of operating the groundwater system is relatively low, the net benefit of continuing to use groundwater for snow-melting becomes negative only if the impact on fishery productivity is substantial. Under current conditions, this is unlikely to occur at our study site because the differences in snow-melting costs, between groundwater and each of the alternatives, are orders of magnitude higher than the estimated fishery loss. In other words, a negative net benefit for snow-melting using groundwater would require that the impact on fishery production and net revenue is much higher than is currently estimated. Note, however, that because our analysis only included costs and benefits that the available data allowed us to monetize, we are underestimating the full cost of using groundwater for snow-melting. Besides the direct tradeoff between snow-melting and other aboveground consumptive uses of groundwater, there may be additional negative effects of increased withdrawals, such as a reduction in water quality. The estimated cost should therefore be interpreted as a lower bound.

Table 4. The net benefit of increasing groundwater use for snow-melting in Obama by $50 \%$, under different assumptions about alternative melting technologies, number of snow days, and fishing costs (million JPY/year).

\begin{tabular}{|c|c|c|c|c|c|c|c|}
\hline \multicolumn{8}{|c|}{15 Snow Days } \\
\hline & $\begin{array}{c}\text { Manual } \\
\text { (Retired) }\end{array}$ & $\begin{array}{c}\text { Manual } \\
\text { (Market) }\end{array}$ & Heat Pump & Oil & Gas & Filament & Air Pump \\
\hline Low fishing cost & 171.5 & 283.1 & 10.9 & 30.3 & 43.8 & 86.5 & 39.7 \\
\hline High fishing cost & 171.6 & 283.2 & 11.1 & 30.5 & 43.9 & 86.7 & 39.9 \\
\hline \multicolumn{8}{|c|}{29 Snow Days } \\
\hline & $\begin{array}{c}\text { Manual } \\
\text { (Retired) }\end{array}$ & $\begin{array}{c}\text { Manual } \\
\text { (Market) }\end{array}$ & Heat Pump & Oil & Gas & Filament & Air Pump \\
\hline Low fishing cost & 331.8 & 547.6 & 21.4 & 59.0 & 85.0 & 167.6 & 77.1 \\
\hline High fishing cost & 332.0 & 547.7 & 21.6 & 59.1 & 85.1 & 167.7 & 77.2 \\
\hline
\end{tabular}

As mentioned previously, one important caveat is that the effect of increased pumping for snow-melting on fish productivity may linger beyond the winter months. If that is indeed the case, our calculated fishery losses underestimate the true impact of increased pumping. Nevertheless, even if we instead assumed that the SGD effect continued year-round, the net benefit of increased groundwater used for melting snow would remain positive, provided that the other assumptions underlying the analysis remain unchanged. In addition, our analysis did not consider the life cycle of fish species, nor the possibility of heterogeneous effects across species. It is possible, for example, that reduced SGD has a larger impact on juveniles than adults and/or reduces productivity more severely for particular species [28]. The inclusion of a dynamic population model for fish and a better understanding of how SGD affects specific species would help to address these limitations.

The economic analysis was undertaken with aggregate societal welfare in mind. Therefore, questions related to distribution of benefits and costs across industries and individuals were not addressed. Although the estimated loss to the fishery is relatively small compared to overall social benefits in our pumping scenario, the concentration of losses within a single sector could be viewed as inequitable. One way to address this issue would be to reallocate some of the cost savings realized by the local government to the affected fishermen through a financial assistance program. 


\section{Conclusions}

In Obama City, Japan, we investigated the impacts of using groundwater for snow-melting during the winter on a nearshore marine resource. Local stakeholder interest in better understanding this tradeoff was driven by both the desire to protect a locally important fishery, as well as concerns about the future scarcity of water resources in the prefecture, which currently depends on groundwater for $70 \%$ of its municipal use. Applying standard benefit-cost techniques, we found that the benefits of increasing the use of groundwater for snow-melting by $50 \%$, of the current rate, outweigh the costs to the nearshore fishery by 10.9 to 547.7 million JPY/year. However, the costs should be viewed as a lower bound as we were not able to monetize other potential costs of groundwater withdrawals. In addition, the estimated fishery impact would likely be higher if species-specific dynamic fish population models could be incorporated into the analysis.

Although the quantitative results presented here are specific to our study site, the methods developed can be applied to other regions where the protection of groundwater-dependent ecosystems is a concern. The challenge of balancing multiple uses of freshwater has been increasingly recognized globally, particularly given the potential for climate change to exacerbate freshwater scarcity. Future research in this area would benefit from efforts to integrate water-energy-food nexus frameworks with inclusive ecosystem valuation approaches that account for multiple (monetized and non-monetized) values in a systematic way.

Author Contributions: Conceptualization, K.M.B., C.A.W., and M.T.; methodology, K.M.B., C.A.W., and M.T.; formal analysis, C.A.W. and R.S.; data curation, C.A.W., M.T., R.S., and D.T.; writing-original draft preparation, K.M.B. and C.A.W.; writing_-review and editing, K.M.B., C.A.W., and M.T.; visualization, C.A.W., M.T., and R.S.; and funding acquisition, M.T.

Funding: This research was supported by the Research Institute for Humanity and Nature (RIHN: a constituent member of NIHU) Project No. 14200097, entitled "Human-Environmental Security in Asia-Pacific Ring of Fire: Water-Energy-Food Nexus".

Conflicts of Interest: The authors declare no conflicts of interest. The funding sponsors had no role in the design of the study; in the collection, analyses, or interpretation of data; in the writing of the manuscript, and in the decision to publish the results.

\section{References}

1. Japanese Ministry of Land, Infrastructure, Transport and Tourism. Current State of Water Resources in Japan; 2008. Available online: http://www.mlit.go.jp/tochimizushigen/mizsei/water_resources (accessed on 1 February 2018).

2. The Report of Economic Evaluation Research on the Project of Human-Environmental Security in Asia-Pacific Ring of Fire: Water-Energy-Food Nexus. Research Institute for Natural Capital, Co., Ltd.: Tokyo, Japan, 2014.

3. Intergovernmental Panel on Climate Change (IPCC). The Regional Impacts of Climate Change: An Assessment of Vulnerability; Cambridge University Press: Cambridge, UK, 1997; p. 517.

4. Organization for Economic Co-operation and Development (OECD). Water and Climate Change Adaptation: Policies to Navigate Uncharted Waters; OECD Studies on Water; OECD Publishing: Paris, France, 2013.

5. Gemma, M.; Tsur, Y. The Stabilization Value of Groundwater and Conjunctive Water Management under Uncertainty. Appl. Econ. Perspect. Policy 2007, 29, 540-548. [CrossRef]

6. Tsur, Y.; Graham-Tomasi, T. The buffer value of groundwater with stochastic surface water supplies. J. Environ. Manag. 1991, 21, 201-224. [CrossRef]

7. Brown, J.; Bach, L.; Aldous, A.; Wyers, A.; De Gagné, J. Groundwater-dependent ecosystems in Oregon: An assessment of their distribution and associated threats. Front. Ecol. Environ. 2011, 9, 97-102. [CrossRef]

8. Howard, J.; Merrifield, M. Mapping Groundwater Dependent Ecosystems in California. PLoS ONE 2010, 5, e11249. [CrossRef] [PubMed]

9. Moosdorf, N.; Oehler, T. Societal use of fresh submarine groundwater discharge: An overlooked water resource. Earth-Sci. Rev. 2017, 171, 338-348. [CrossRef]

10. Moya, T.; Boulton, A.J. Ecology and management of subsurface groundwater dependent ecosystems in Australia-A review. Mar. Freshw. Res. 2010, 61, 936-949. 
11. Murray, B.R.; Zeppel, M.J.B.; Hose, G.C.; Eamus, D. Groundwater-dependent ecosystems in Australia: It's more than just water for rivers. Ecol. Manag. Restor. 2003, 4, 110-113. [CrossRef]

12. MacKay, H. Protection and management of groundwater-dependent ecosystems: Emerging challenges and potential approaches for policy and management. Aust. J. Bot. 2006, 54, 231-237. [CrossRef]

13. Burnett, K.; Pongkijvorasin, S.; Roumasset, J.; Wada, C.A. Incentivizing interdependent resource management: Watersheds, groundwater, and coastal ecology. In Handbook of Water Economics; Dinar, A., Schwabe, K., Eds.; Edward Edgar Publishing: Cheltenham/Northampton, UK, 2015; pp. 150-161.

14. Foster, S.; Koundouri, P.; Tuinhof, A.; Kemper, K.; Nanni, M.; Garduno, H. Groundwater Dependent Ecosystems: The Challenge of Balanced Assessment and Adequate Conservation; GW Mate Briefing Note Series No. 15; World Bank: Washington, DC, USA, 2006.

15. Rohde, M.M.; Froend, R.; Howard, J. A Global Synthesis of Managing Groundwater Dependent Ecosystems under Sustainable Groundwater Policy. Groundwater 2017, 55, 293-301. [CrossRef] [PubMed]

16. Burnett, K.; Wada, C.; Endo, A.; Taniguchi, M. The economic value of groundwater in Obama. J. Hydrol. Reg. Stud. 2017, 11, 44-52. [CrossRef]

17. Konikow, L.F.; Kendy, E. Groundwater depletion: A global problem. Hydrogeol. J. 2005, 13, 317-320. [CrossRef]

18. Final Report of Groundwater Investigation in Obama. Nippon Koei Co., Ltd.: Tokyo, Japan, 2016.

19. Lalli, C.M.; Parsons, T.R. Biological Oceanography: An Introduction, 2nd ed.; Elsevier: Burlington, MA, USA, 1997; 306p, ISBN 978-0-7506-3384-0.

20. Dadhich, A.P.; Nadaoka, K.; Motomura, Y.; Watanabe, A. Potential impacts of land use change dynamics and submarine groundwater discharge on fringing reefs of Kuroshima Island, Japan. J. Coast. Conserv. 2017, 21, 245-254. [CrossRef]

21. Piló, D.; Barbosa, A.B.; Teodósio, M.A.; Encarnação, J.; Leitão, F.; Range, P.; Krug, L.A.; Cruz, J.; Chícharo, L. Are submarine groundwater discharges affecting the structure and physiological status of rocky intertidal communities? Mar. Environ. Res. 2018, 136, 158-173. [CrossRef] [PubMed]

22. Shoji, J.; Tominaga, O. Relationships between Submarine Groundwater Discharge and Coastal Fisheries as a Water-Food Nexus. In The Water-Energy-Food Nexus_Global Environmental Studies; Endo, A., Oh, T., Eds.; Springer: Singapore, 2018; pp. 117-131.

23. Main Fish Catch Landed in Obama Market; Obama Branch of the Fishery Association of Fukui Prefecture: Fukui, Japan, December 2017.

24. Fishery Management Statistics; Ministry of Agriculture, Forestry, and Fisheries of Japan: Tokyo, Japan, 2015.

25. Water Supply and Sewerage Costs; Obama City Office: Fukui, Japan, 2018.

26. Sugimoto, R.; Honda, H.; Kobayashi, S.; Takao, Y.; Tahara, D.; Tominaga, O.; Taniguchi, M. Seasonal Changes in Submarine Groundwater Discharge and Associated Nutrient Transport into a Tideless Semi-enclosed Embayment (Obama Bay, Japan). Estuaries Coasts 2016, 39, 13-26. [CrossRef]

27. Tominaga, O.; Makita, T. Contribution of terrestrial organic matter to benthic bioproduction in coastal areas. In Linkage of Forests, Rivers and Coasts and Biological Production in Estuarine and Coastal Waters; Yamashita, Y., Tanaka, M., Eds.; Koseisha-Koseikaku: Tokyo, Japan, 2008; pp. 46-58.

28. Hata, M.; Sugimoto, R.; Hori, M.; Tomiyama, T.; Shoji, J. Occurrence, distribution and prey items of juvenile marbled sole Pseudopleuronectes yokohamae around a submarine groundwater seepage on a tidal flat in southwestern Japan. J. Sea Res. 2016, 111, 47-53. [CrossRef]

(c) 2018 by the authors. Licensee MDPI, Basel, Switzerland. This article is an open access article distributed under the terms and conditions of the Creative Commons Attribution (CC BY) license (http://creativecommons.org/licenses/by/4.0/). 